\title{
ACTIVATION OF OIL PALM EMPTY BUNCHES WITH HYDROCHLORIDE ACID \& PHOSPHORIC ACID AND CHARACTERIZATION BASED SNI NO. 06-3730-1995
}

\author{
Irna Diah Mumpuni ${ }^{1)}$, Mamay Maslahat ${ }^{2)^{*}}$, Devy Susanty ${ }^{2)}$ \\ ${ }^{1)}$ PT Mitra Sukses Agrindo \\ Jl. K.H. Soleh Iskandar No.59 Bogor 16166 \\ ${ }^{2)}$ Program Studi Kimia, FMIPA, Universitas Nusa Bangsa \\ Jl. K.H. Sholeh Iskandar Km. 4 Cimanggu Tanah Sareal, Bogor 16166
}

\section{ARTICLE INFO}

Article history:

Received 27 Jan 2021,

Accepted 22 Apr 2021

Available online 29 Apr 2021

$$
\begin{aligned}
& \text { Keywords: } \\
& \checkmark \text { Activated Carbon } \\
& \checkmark \text { Iodine Absorption } \\
& \checkmark \text { Oil Palm Empty Fruit } \\
& \text { Bunches }
\end{aligned}
$$

*corresponding author: maymaslahat.sasmita@gmail . .com

Phone: +6285696371182

https://doi.org/10.31938/jsn.v $\underline{11 \mathrm{i} 1.291}$

\begin{abstract}
Activated carbon is a solid product resulting from carbonization and activation of lignocellulosic biomass by several methods and activators. Each activator can produce different characteristics of activated carbon. The activated carbon of Oil Palm Empty Fruit Bunches (OPEFB) is processed from Empty Fruit Bunches (EFB) waste, which is quite abundant in Indonesia. The purpose of this study was to determine the characteristics of OPEFB carbon that had been chemically activated using hydrochloric acid $(\mathrm{HCl})$ and phosphoric acid $\left(\mathrm{H}_{3} \mathrm{PO}_{4}\right)$ based on the Indonesian National Standard (SNI) No. 06 - 3730 - 1995. The research method consisted of the process of carbonization of OPEFB using a pyrolysis device at $400^{\circ} \mathrm{C}$ for 6 hours; activation of carbon with activator $\mathrm{HCl}$ and $\mathrm{H}_{3} \mathrm{PO}_{4}$ at various activator concentrations; characterization of activated carbon on the parameters of moisture content, ash content, absorption of iodine, and absorption of methylene blue. The results showed that the $0.5000 \mathrm{M} \mathrm{HCl}$ was the best activator that produced the quality of OPEFB activated carbon according to SNI 06 3730 - 1995 on parameters of moisture content, ash content and absorption of iodine.
\end{abstract}

\section{ABSTRAK}

Aktivasi karbon tandan kosong kelapa sawit dengan asam klorida dan asam fosfat serta uji karakterisasi berdasarkan SNI No. 06 $3730-1995$

Karbon aktif merupakan produk padatan yang dihasilkan dari karbonisasi dan aktivasi biomassa lignoselulosa dengan beberapa metode dan aktivator. Masing-masing aktivator dapat menghasilkan karakteristik karbon aktif yang berbeda. Karbon aktif Tandan Kosong Kelapa Sawit (TKKS) diolah dari limbah TKKS yang keberadaannya cukup melimpah di Indonesia. Tujuan penelitian ini adalah mengetahui karakteristik karbon TKKS yang telah diaktivasi secara kimia menggunakan aktivator asam klorida $(\mathrm{HCl})$ dan asam fosfat $\left(\mathrm{H}_{3} \mathrm{PO}_{4}\right)$ berdasarkan Standar Nasional Indonesia (SNI) No. 06 - 3730 - 1995. Metode penelitian terdiri atas proses karbonisasi TKKS menggunakan alat pirolisis pada suhu 400 ${ }^{\circ} \mathrm{C}$ selama 6 jam; aktivasi karbon dengan aktivator $\mathrm{HCl}$ dan $\mathrm{H}_{3} \mathrm{PO}_{4}$ pada berbagai konsentrasi aktivator; serta karakterisasi karbon aktif pada parameter kadar air dan abu, daya jerap terhadap iod serta daya jerap terhadap biru metilen. Hasil penelitian menunjukkan bahwa $\mathrm{HCl}$ 0,5 M merupakan aktivator terbaik dan karbon aktif yang dihasilkan memiliki karakteristik yang sesuai dengan SNI 06 - 3730 - 1995 pada parameter kadar air dan abu serta daya jerap terhadap iod.

Kata kunci: Daya Jerap Iod, Karbon Aktif, Tandan Kosong Kelapa Sawit

\section{PENDAHULUAN}

Pada bidang industri, kebutuhan Indonesia terhadap karbon aktif masih relatif tinggi (Miranti,
2012), sehingga untuk memenuhinya Indonesia masih melakukan impor. Data impor karbon aktif Indonesia cenderung meningkat setiap tahun dengan kecenderungan peningkatan sekitar 5,86\% terhitung dari tahun 2012- 2016. Tahun 2016 
tercatat impor karbon aktif cukup tinggi yaitu senilai 16.175.200 US\$ (Kemenperin, 2017).

Karbon aktif berbentuk amorf memiliki luas permukaan sekitar $300-2000 \mathrm{~m}^{2} / \mathrm{g}$ (Ramdja et al., 2008). Luas permukaan yang besar pada karbon aktif disebabkan oleh adanya pori. Keberadaan pori ini menyebabkan karbon aktif memiliki kemampuan menjerap. Karbon aktif dihasilkan dari tiga proses, yaitu proses dehidrasi, karbonisasi, dan proses aktivasi. Tujuan aktivasi adalah memperbesar pori dengan memecah ikatan hidrokarbon. Oksidasi molekul pada permukaan dapat merubah sifat kimia dan fisika karbon sehingga menjadi aktif dan memiliki kemampuan menjerap.

Jumlah TKKS di Indonesia yang sangat melimpah merupakan limbah pabrik kelapa sawit. Setiap 1 ton Tandan Buah Segar (TBS), akan menghasilkan TKKS sekitar $220-230 \mathrm{~kg}$. Masyarakat maupun Pabrik Kelapa Sawit (PKS) belum memanfaatkan limbah tersebut dengan optimal. Limbah TKKS berpotensi sebagai karbon aktif karena mengandung lignoselulosa.

Pada penelitian sebelumnya telah diperoleh karbon aktif TKKS yang memiliki karakteristik sesuai SNI pada parameter daya jerap terhadap iod dan zat warna biru metilen, karbon tersebut hasil aktivasi secara fisika menggunakan pemanasan oven suhu $800{ }^{\circ} \mathrm{C}$ (Maslahat et al., 2019). Pada penelitian ini, dilakukan aktivasi terhadap karbon TKKS menggunakan aktivasi kimia yaitu asam klorida $(\mathrm{HCl})$ dan asam fosfat $\left(\mathrm{H}_{3} \mathrm{PO}_{4}\right)$. Asam klorida dan asam fosfat merupakan aktivator. Asam klorida berperan sebagai dehidrat pada karbon aktif. Penggunaan aktivator fosfat membantu memperluas pori dan meningkatkan nilai rendemen. Konsentrasi $\mathrm{HCl}$ dan $\mathrm{H}_{3} \mathrm{PO}_{4}$ yang digunakan cukup tinggi agar lebih mempermudah proses pelarutan pengotor-pengotor pada permukaan karbon, pori-pori menjadi akan terbuka dan permukaan karbon aktif semakin luas (Rahayu dan Adhitiyawarman, 2014).

\section{BAHAN DAN METODE}

\section{Bahan dan Alat}

Bahan untuk penelitian terdiri dari limbah TKKS, larutan $\mathrm{Na}_{2} \mathrm{~S}_{2} \mathrm{O}_{3} 0,1 \mathrm{~N}$ (Merck), $\mathrm{Na}_{2} \mathrm{CO}_{3}$ (Merck), larutan iodin 0,1 N (Merck), kalium dikromat (Merck), kertas saring Whattman No. 40, larutan $\mathrm{HCl}$ (Merck) dengan konsentrasi 0,5000; 1,0000; 1,5000; 2,0000; dan 2,5000 M, larutan $\mathrm{H}_{3} \mathrm{PO}_{4}$ (Merck) dengan konsentrasi 10,00; 12,50; 15,00; 17,50 dan 20,00 \%, kalium iodida (Merck) $10,00 \%$, larutan amilum 1,00 \%, akuades dan biru metilen (Merck).

Peralatan yang digunakan dalam penelitian terdiri dari alat pirolisis, penggiling atau penumbuk, tanur, oven, saringan, timbangan analitik, magnetic stirer, spatula, wadah plastik, peralatan gelas, dan spektrofotometer LW Scientific UV-200-RS.

\section{Metode}

\section{Pengambilan Sampel TKKS}

Sampel limbah TKKS didapatkan dari PT Perkebunan Nusantara VIII Kelapa Sawit Cikasungka, Cigudeg, kabupaten Bogor.

\section{Persiapan Bahan/Preparasi Bahan}

Sampel TKKS dicacah menjadi ukuran lebih kecil, dicuci dengan air mengalir dan dikeringkan selama 1 minggu menggunakan panas sinar matahari.

\section{Proses Karbonisasi}

Sampel TKKS kering dikarbonisasi pada suhu $400{ }^{\circ} \mathrm{C}$ selama 6 jam menggunakan alat pirolisis dengan sedikit udara. Karbon yang terbentuk didinginkan, ditumbuk dan disaring menggunakan saringan ukuran 100 mesh (Kurniati, 2008).

\section{Proses Aktivasi Aktivator $\mathrm{HCl}$}

Karbon yang telah diperoleh direndam dalam $\mathrm{HCl} 0,5000 ; 1,0000 ; 1,5000 ; 2,0000$; dan 2,5000 M selama 24 jam. Perbandingan karbon dengan aktivator adalah $1: 5$. Setelah direndam, dilakukan penyaringan dan dicuci untuk mendapatkan $\mathrm{pH}$ netral menggunakan akuades. Residu dikeringkan pada suhu oven $110{ }^{\circ} \mathrm{C}$ selama 3 jam. Karbon didinginkan dalam desikator dan diperoleh karbon yang telah teraktivasi.

\section{Aktivator $\mathrm{H}_{3} \mathrm{PO}_{4}$}

Karbon TKKS direndam dalam larutan $\mathrm{H}_{3} \mathrm{PO}_{4}$ 10,$00 ; 12,50 ; 15,00 ; 17,50$ dan 20,00\% dengan perbandingan 1 : 5 selama 24 jam. Setelah perendaman selesai dilakukan penyaringan dan pencucian dengan akuades sampai $\mathrm{pH}$ netral. 
Pengeringan residu dilakukan menggunakan oven selama 3 jam pada suhu $110{ }^{\circ} \mathrm{C}$ (Sahara et al., 2017).

Uji Kualitas Karbon Aktif (SNI No. 06-37301995)

\section{Penetapan Kadar Air}

Sebanyak 1 gram karbon aktif TKKS ditimbang (bobot sampel awal), kemudian dipanaskan selama 3 jam pada pada suhu $110{ }^{\circ} \mathrm{C}$ menggunakan oven. Setelah itu, karbon aktif didinginkan dalam desikator, kemudian ditimbang hingga diperoleh bobot yang konstan.

\section{Penetapan Kadar Abu}

Sebanyak 1 gram karbon aktif TKKS ditimbang (bobot sampel awal), kemudian dipanaskan selama 4 jam pada suhu $600{ }^{\circ} \mathrm{C}$ menggunakan tanur. Untuk menyempurnakan pengabuan, tutup tanur dibuka selama 1 menit setelah selesai pemanasan. Abu dari karbon aktif dimasukkan ke dalam desikator, kemudian ditimbang hingga diperoleh bobot konstan sebagai bobot abu (Akbar, 2011).

\section{Penetapan Daya Jerap terhadap Iod}

Sebanyak 1 gram karbon aktif TKKS dikeringkan selama 3 jam pada suhu $110{ }^{\circ} \mathrm{C}$ Karbon aktif yang telah dipanaskan didinginkan dalam desikator. Karbon aktif kering dimasukkan ke dalam Erlenmeyer. Larutan iodin $0,1 \mathrm{~N}$ dimasukkan ke erlenmeyer sebanyak $50 \mathrm{~mL}$ kemudian diaduk selama 15 menit menggunakan magnetic stirrer. Filtrat diperoleh dengan cara penyaringan. Sebanyak $10 \mathrm{~mL}$ filtrat ditritasi dengan larutan $\mathrm{Na}_{2} \mathrm{~S}_{2} \mathrm{O}_{3} \quad 0,1 \quad \mathrm{~N}$ dengan menambahkan amilum $1 \%$ hingga diperoleh larutan tidak berwarna (Akbar, 2011). Rumus menghitung daya jerap terhadap larutan iod adalah sebagai berikut (ASTM D 4607 - 94, 2014).

Daya jerap terhadap larutan Iod $(\mathrm{mg} / \mathrm{g})=$

$$
\frac{A-(f p \times B \times V)}{w} \frac{A-(f p \times B \times V)}{w}
$$

Keterangan:

W : bobot karbon aktif (g)

fp : faktor pengenceran

$\mathrm{V}$ : volume $\mathrm{Na}_{2} \mathrm{~S}_{2} \mathrm{O}_{3} 0,1 \mathrm{~N}$
A : N2 x 12693,0
B : N1 $x 126,93$
$\mathrm{N} 1$ : normalitas $\mathrm{Na}_{2} \mathrm{~S}_{2} \mathrm{O}_{3}$
$\mathrm{N} 2:$ normalitas $\mathrm{I}_{2}$

\section{Penetapan Daya Serap terhadap Biru Metilen}

Pada tahap awal, karbon aktif TKKS dipanaskan selama 1 jam pada suhu $105 \pm 5{ }^{\circ} \mathrm{C}$ menggunakan oven, kemudian didinginkan di dalam desikator. Sebanyak $0,5 \mathrm{~g}$ karbon aktif TKKS dimasukkan ke dalam Erlenmeyer dan dicampurkan dengan larutan biru metilen 1000 $\mathrm{mg} / \mathrm{L}$ sebanyak $100 \mathrm{~mL}$, kemudian diaduk selama 30 menit. Setelah itu, penyaringan dilakukan untuk memisahkan larutan biru metilen dengan karbon aktif TKKS, sehingga diperoleh filtrat. Absorbansi filtrat diukur menggunakan spektrofotometer UVVIS pada lamda maksimum $664 \mathrm{~nm}$. Kurva standar larutan biru metilen dibuat dengan konsentrasi antara 1 sampai 6 ppm. Kapasitas adsorpsi (Q) dan efisiensi adsorpsinya (EA) dihitung dengan rumus (Akbar, 2011):

Kapasitas adsorpsi (Q)

$$
\text { (Q) }(\mathrm{mg} / \mathrm{g})=\frac{(\mathrm{Vx}(\mathrm{Ca}-\mathrm{Cb}))(\mathrm{Vx}(\mathrm{Ca}-\mathrm{Cb}))}{\mathrm{w}}
$$

Efisiensi adsorpsi (EA)

$$
\text { (EA) }(\%)=\frac{\mathrm{Ca}-\mathrm{Cb}}{\mathrm{Ca}} \times 100 \%
$$

Keterangan:

$\mathrm{V}$ : volume biru metilen (L)

$\mathrm{Ca}$ : konsentrasi awal biru metilen $(\mathrm{mg} / \mathrm{L})$

$\mathrm{Cb}$ : konsentrasi akhir biru metil (mg/L)

$\mathrm{Fp}$ : faktor pengenceran

W : bobot karbon aktif (g).

\section{HASIL DAN PEMBAHASAN}

\section{Limbah TKKS}

Pada tahap preparasi sampel dilakukan proses pencucian limbah TKKS yang sudah dicacah menggunakan air mengalir bertujuan membersihkan TKKS dari jamur agar memudahkan proses karbonisasi. Proses pengeringan limbah TKKS dilakukan dengan tujuan untuk menghilangkan air yang terkandung 
dalam limbah TKKS sehingga didapatkan TKKS kering yang siap untuk dikarbonisasi.

\section{Karbonisasi TKKS}

Pada proses karbonisasi terjadi penyusutan sampel. Limbah TKKS yang digunakan sebanyak $35 \mathrm{Kg}$ menghasilkan karbon sebesar $8,5 \mathrm{Kg}$, sehingga persen rendemennya adalah $24,29 \%$. Penyusutan bobot ini terjadi karena pemanasan pada karbonisasi yang dapat mengakibatkan hilangnya berbagai komponen lainnya. Beberapa komponen yang hilang adalah tar, asam - asam dan aldehid - aldehid termasuk hidrogen yang terikat pada karbon. Proses karbonisasi dilakukan menggunakan alat pirolisis pada suhu $400{ }^{\circ} \mathrm{C}$ selama 6 jam. Penghalusan karbon setelah karbonisasi bertujuan agar ukuran partikel karbon homogen dan memiliki permukaan yang lebih luas. Permukaan yang lebih luas akan memperbanyak terjadinya kontak pada saat aktivasi sehingga jumlah karbon teraktivasi dan pori-pori yang terbentuk akan banyak jumlahnya.

\section{Aktivasi Karbon TKKS}

Aktivasi karbon TKKS dilakukan menggunakan bahan kimia dengan cara perendaman. Pada penelitian ini digunakan $\mathrm{HCl}$ dan $\mathrm{H}_{3} \mathrm{PO}_{4}$ sebagai aktivator. Proses aktivasi ini bertujuan untuk membentuk pori yang lebih banyak dengan pemecahan ikatan hidrokarbon (Faradina dan Setiawati, 2010). Pada proses aktivasi terjadi perubahan massa yang disebabkan oleh terjadinya proses pembentukan dan penyusunan struktur karbon. Proses ini mengakibatkan terbentuknya pori dan berkurangnya jumlah karbon. Semakin banyak pori maka akan mempermudah penyerapan (Meisrilestari et al., 2013).

Berdasarkan Gambar 1, terlihat bahwa pada proses aktivasi dengan aktivator $\mathrm{HCl}$ didapatkan rendemen karbon aktif berkisar antara 91,67 $97,34 \%$. Rendemen karbon aktif tertinggi terdapat pada perlakuan karbon yang direndam dengan $\mathrm{HCl}$ 1,5 M, sedangkan yang terendah adalah perlakuan karbon yang direndam dengan $\mathrm{HCl}$ 0,5 M.

Aktivasi karbon TKKS menggunakan asam fosfat menunjukan bahwa larutan aktivator $\mathrm{H}_{3} \mathrm{PO}_{4}$ $17,5 \%$ memiliki rendemen karbon aktif yang tertinggi, sedangkan larutan aktivator $\mathrm{H}_{3} \mathrm{PO}_{4}$ 12,5 $\%$ menghasilkan rendemen yang terendah yaitu sebesar $80,24 \%$, sebagaimana yang ditunjukkan pada Gambar 2. Persen rendemen karbon aktif yang diaktivasi dengan $\mathrm{H}_{3} \mathrm{PO}_{4}$ lebih rendah jika dibandingkan dengan aktivator $\mathrm{HCl}$. Karbon sebelum dan setelah aktivasi memberikan warna yang sama yaitu hitam mengkilat dan bertektur halus (Gambar 3).

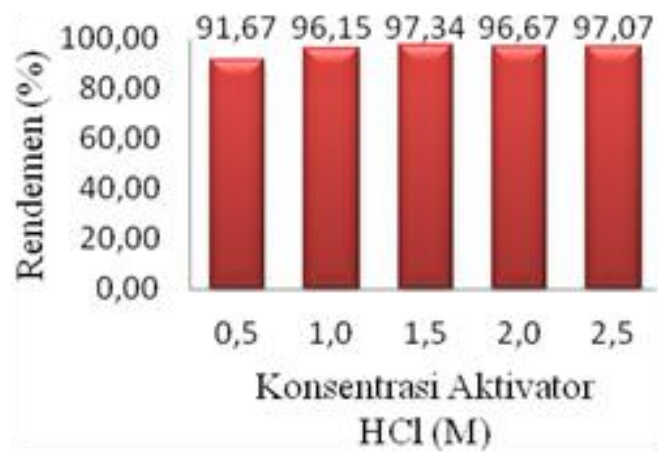

Gambar 1. Rendemen Karbon Aktif dengan Aktivator $\mathrm{HCl}$

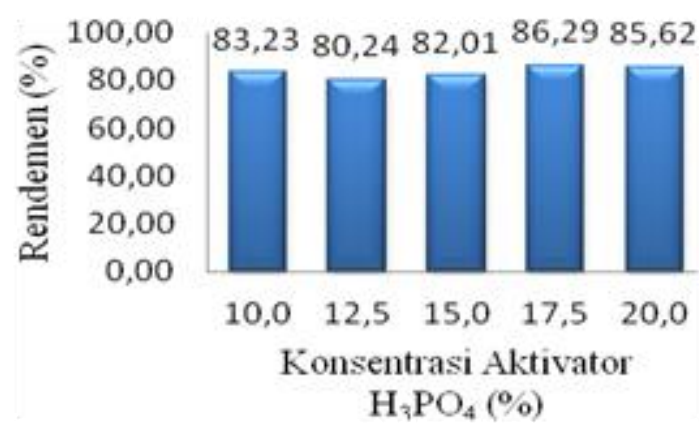

Gambar 2. Rendemen Karbon Aktif dengan Aktivator $\mathrm{H}_{3} \mathrm{PO}_{4}$

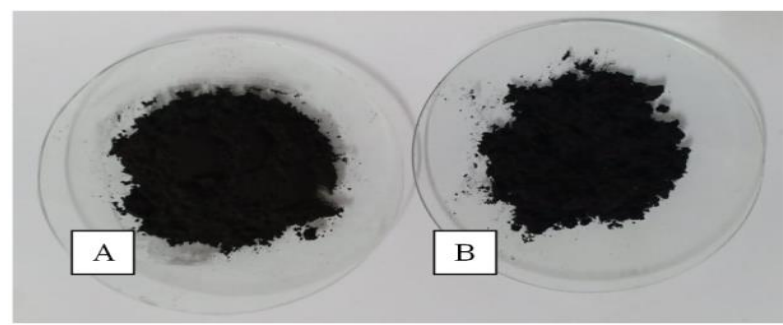

Gambar 3. Karbon (A) dan Karbon Aktif (B)

\section{Karakteristik Karbon Aktif TKKS}

Karakterisasi karbon aktif diuji berdasarkan Standar Nasional Indonesia (SNI) 06 - 3730 1995, dengan parameter meliputi kadar air, kadar abu, daya jerap terhadap iod dan daya jerap terhadap biru metilen. Metode untuk menilai kinerja adsorpsi dari karbon aktif cukup banyak 
diantaranya yang sering digunakan sebagai nilai evaluasi adalah daya jerap iod, yang didefinisikan sebagai jumlah miligram iod yang terjerap ke dalam 1 gram karbon aktif. Dengan mengetahui daya jerap karbon aktif terhadap iod, akan diketahui kemampuan karbon aktif menjerap zat dengan ukuran molekul $10 \dot{\mathrm{A}}$ sehingga memberi indikasi jumlah pori 10-15 $\dot{\mathrm{A}}$. Zat pewarna metilen biru merupakan pewarna yang umum digunakan di industri tekstil dengan ukuran molekul $19 \mathrm{~nm}$ dan metilen biru memiliki tingkat jerapan yang kuat pada padatan sehingga umum digunakan sebagai model senyawa yang relevan dengan adsorpsi molekul organik dalam bentuk larutan. Adsorpsi metilen biru juga dapat digunakan sebagai parameter penentuan sisi polar dari karbon aktif, makin tinggi nilai adsorpsi maka disinyalir karbon aktif lebih bersifat polar. Benzena merupakan molekul senyawa organik yang mudah menguap yang banyak digunakan di industri kimia, yang bersifat beracun terhadap kesehatan manusia walaupun pada konsentrasi kecil. Selain itu, karakterisasi karbon aktif dapat dilakukan melalui penentuan gugus fungsi, kristalinitas dan morfologi karbon aktif masing-masing menggunakan instrumen Fourier Transform Infra
Red (FTIR), X-Ray Diffraction (XRD) dan Scanning Electron Microscope (SEM) (Effiyanti et al, 2020). Instrumen Energy Dispersive X-Ray (EDX) dan Surface Area Analyzer (SAA) dapat digunakan pula untuk kepentingan karakterisasi karbon aktif (Hardi, et.al, 2020). Karakteristik karbon aktif TKKS hasil aktivasi menggunakan larutan $\mathrm{HCl}$ ditunjukkan pada Tabel 2, sedangkan hasil aktivasi menggunakan larutan asam fosfat ditunjukkan oleh Tabel 3. Pembanding yang digunakan adalah SNI arang aktif (Tabel 1).

\section{Kadar Air}

Karbon aktif hasil aktivasi dengan $\mathrm{HCl}$ 0,5 M memiliki kadar air yang terendah yaitu sebesar $10,93 \%$, sedangkan yang tertinggi adalah karbon aktif yang diaktivasi dengan $\mathrm{HCl} 2,5 \mathrm{M}$ yaitu sebesar 14,82 \% (Tabel 1). Karbon aktif hasil aktivasi dengan $\mathrm{H}_{3} \mathrm{PO}_{4} 10 \%$ memiliki kadar air terendah yaitu sebesar $9,32 \%$, sedangkan kadar air tertinggi dihasilkan dari karbon aktif yang diaktivasi dengan $\mathrm{H}_{3} \mathrm{PO}_{4} 20 \%$ yaitu sebesar 12,60 $\%$ (Tabel 2). Hasil tersebut memenuhi standar kualitas karbon aktif berdasarkan SNI 06 - 3730 1995 yaitu maksimal $15 \%$ untuk karbon aktif berbentuk serbuk.

Tabel 1. Persyaratan Karbon Aktif Berdasarkan SNI 06-3730-1995

\begin{tabular}{|c|c|}
\hline Jenis Parameter & Persyaratan \\
\hline Kadar air & Maks $15 \%$ \\
\hline Kadar abu & Maks $10 \%$ \\
\hline Kadar zat menguap & Maks $25 \%$ \\
\hline Kadar karbon terikat & $\operatorname{Min} 65 \%$ \\
\hline Daya jerap terhadap yodium & Min $750 \mathrm{mg} / \mathrm{g}$ \\
\hline Daya jerap terhadap benzene & $\operatorname{Min} 25 \%$ \\
\hline Daya jerap terhadap biru metilen & $120 \mathrm{mg} / \mathrm{g}$ \\
\hline
\end{tabular}

Tabel 2. Karakteristik Karbon Aktif TKKS Hasil Aktivasi dengan $\mathrm{HCl}$

\begin{tabular}{llllll}
\hline \multicolumn{1}{c}{ Parameter } & \multicolumn{5}{c}{ Konsentrasi HCl (M) } \\
\cline { 2 - 6 } & \multicolumn{1}{c}{0,5000} & 1,0000 & 1,5000 & 2,0000 & 2,5000 \\
\hline Kadar Air (\%) & 10,93 & 12,59 & 13,69 & 13,76 & 14,82 \\
Kadar Abu (\%) & 6,73 & 7,55 & 7,94 & 8,36 & 8,71 \\
Daya Jerap terhadap Iod (mg/g) & 753,06 & 727,78 & 703,1 & 687,10 & 713,30 \\
Daya Jerap terhadap Biru Metilen & 114,35 & 101,16 & 90,13 & 110,35 & 98,18 \\
\hline
\end{tabular}

Tabel 3. Karakteristik Karbon Aktif TKKS Hasil Aktivasi dengan $\mathrm{H}_{3} \mathrm{PO}_{4}$

\begin{tabular}{llllll}
\multicolumn{1}{c}{ Parameter } & \multicolumn{5}{c}{ Konsentrasi $\mathrm{H}_{3} \mathrm{PO}_{4}(\%)$} \\
\cline { 2 - 6 } & \multicolumn{1}{c}{10,00} & 12,50 & 15,0 & 17,50 & 20,00 \\
\hline Kadar Air (\%) & 10,52 & 12,60 & 11,25 & 9,32 & 11,24 \\
Kadar Abu (\%) & 8,27 & 9,31 & 9,85 & 10,68 & 11,39 \\
Daya Jerap terhadap Iod (mg/g) & 716,48 & 711,71 & 708,43 & 716,00 & 702,00 \\
Daya Jerap terhadap Biru Metilen (mg/g) & 105,72 & 94,13 & 74,20 & 105,59 & 86,00 \\
\hline
\end{tabular}



Penetapan kadar air dilakukan untuk mengetahui sifat higroskopis karbon aktif. Kadar air cenderung lebih tinggi saat menggunakan aktivator dengan konsentrasi yang lebih tinggi. Penggunaan aktivator bertujuan mengurangi kadar tar yang menyebabkan pori-pori karbon aktif semakin banyak dan besar. Jumlah pori-pori yang banyak dan ukurannya yang besar mengakibatkan meningkatnya penjerapan air sehingga dapat mengakibatkan kadar air menjadi tinggi (Subadra et al., 2005). Mutu karbon menurun jika kadar air pada karbon tersebut tinggi. Hal ini disebabkan oleh berkurangnya daya jerap terhadap molekul yang akan dijerap akibat terhalangi oleh molekul air.

\section{Kadar Abu}

Pada uji kadar abu karbon aktif dengan aktivator $\mathrm{HCl}$ didapatkan hasil kadar abu terendah yaitu pada karbon yang diaktivasi dengan $\mathrm{HCl} 0,5$ $M$ yaitu sebesar $6,73 \%$, sedangkan yang tertinggi dihasilkan oleh karbon yang diaktivasi dengan $\mathrm{HCl}$ 2,5 M yaitu sebesar 8,71\% (Tabel 2). Karbon yang diaktivasi dengan $\mathrm{H}_{3} \mathrm{PO}_{4} 10 \%$ menghasilkan kadar abu yang terendah yaitu sebesar 8,27 \%, sedangkan karbon yang diaktivasi dengan $\mathrm{H}_{3} \mathrm{PO}_{4}$ $20 \%$ menghasilkan kadar abu tertinggi yaitu sebesar 11,39 \% (Tabel 3). Hasil aktivasi karbon TKKS oleh aktivator $\mathrm{HCl}$ dan $\mathrm{H}_{3} \mathrm{PO}_{4}$ pada berbagai konsentrasi menghasilkan nilai kadar abu yang sesuai standar kualitas karbon aktif berdasarkan SNI 06 - 3730 - 1995 yaitu maksimal $10 \%$, kecuali karbon yang diaktivasi oleh aktivator $\mathrm{H}_{3} \mathrm{PO}_{4}$ 17,5 dan $20 \%$. Kadar abu yang tinggi dapat disebabkan oleh terjadinya oksidasi karbon aktif (Pari et al., 2007). Kadar abu menunjukkan kandungan oksida logam pada suatu bahan yang tidak menguap pada proses pengabuan. Kadar abu yang tinggi dapat menghambat penjerapan pada karbon aktif karena terjadinya penyumbatan pori-pori karbon aktif (Laos dan Selan, 2016).

\section{Daya Jerap terhadap Iod}

Penetapan daya jerap iod dilakukan untuk mengetahui kapasitas adsorpsi karbon aktif (Sahara et al., 2017). Kemampuan karbon aktif menjerap iod merepresentasikan kemampuannya dalam menjerap larutan berwarna yang memiliki ukuran $10 \AA$ atau $1 \mathrm{~nm}$ (Pari, 2007). Karbon aktif yang diaktivasi dengan $\mathrm{HCl} 2 \mathrm{M}$ memiliki daya jerap terhadap iod terendah yaitu sebesar 687,35 $\mathrm{mg} / \mathrm{g}$, sedangkan yang diaktivasi dengan $\mathrm{HCl} 0,5$ M menghasilkan daya jerap iod yang tertinggi yaitu sebesar 753,06 mg/g (Tabel 2). Hasil tersebut memenuhi standar kualitas karbon aktif berdasarkan SNI 06 - 3730 - 1995 yaitu sebesar minimal $750 \mathrm{mg} / \mathrm{g}$ (Tabel 1). Karbon aktif yang diaktivasi dengan $\mathrm{H}_{3} \mathrm{PO}_{4} \quad 10,00 \%$ memiliki daya jerap terhadap iod yang terendah yaitu sebesar $702,00 \mathrm{mg} / \mathrm{g}$, sedangkan daya jerap terhadap iod yang tertinggi dihasilkan dari karbon aktif yang diaktivasi dengan $\mathrm{H}_{3} \mathrm{PO}_{4} \quad 10,00 \%$ yaitu sebesar $716,48 \mathrm{mg} / \mathrm{g}$ (Tabel 3). Hasil tersebut tidak memenuhi standar kualitas karbon aktif berdasarkan SNI 06 - 3730 - 1995 yaitu sebesar minimal $750 \mathrm{mg} / \mathrm{g}$.

Penggunaan aktivator $\mathrm{HCl}$ pada karbon aktif memberikan hasil daya jerap iod yang lebih baik daripada penggunaan aktivator $\mathrm{H}_{3} \mathrm{PO}_{4}$. Asam klorida lebih sempurna melarutkan zat organik dan anorganik sehingga membentuk pori-pori yang bersih dan lebih besar pada karbon aktif. Daya jerap iod yang rendah dapat disebabkan oleh terhalangnya permukaan karbon aktif oleh gugus C(CO) yang terbentuk (Smisek dan Cerny, 1970 dalam Pari et al., 1996).

\section{Daya Jerap terhadap Biru Metilen}

Hasil pengujian daya jerap terhadap biru metilen, karbon aktif yang diaktivasi oleh $\mathrm{HCl}$ 0,5000 M memiliki kapasitas adsorpsi yang tertinggi yaitu sebesar $114,35 \mathrm{mg} / \mathrm{g}$ dengan efisiensi adsorpsi sebesar 57,32 \%, sedangkan karbon aktif yang diaktivasi dengan $\mathrm{HCl}$ 1,5 M menghasilkan kapasitas adsorpsi dan efisiensi adsorpsi terendah yaitu sebesar $90,13 \mathrm{mg} / \mathrm{g}$ dan $45,25 \%$ (Gambar 4). Karbon aktif yang diaktivasi oleh $\mathrm{H}_{3} \mathrm{PO}_{4} 15 \%$ memiliki kapasitas adsorpsi terendah yaitu sebesar 74,20 mg/g dengan efisiensi adsorpi sebesar 37,66 \%. Karbon aktif yang diaktivasi dengan $\mathrm{H}_{3} \mathrm{PO}_{4} \quad 10 \%$ menghasilkan kapasitas adsorpsi dan efisiensi adsorpsi tertinggi yaitu sebesar 105,72 mg/g dan 53,82 \% (Gambar 5). Hasil kapasitas adsorpsi tersebut, baik karbon yang diaktivasi dengan $\mathrm{HCl}$ maupun $\mathrm{H}_{3} \mathrm{PO}_{4}$ tidak memenuhi syarat kualitas karbon aktif berdasarkan SNI 06 - 3730 - 1995 yaitu minimal 120 mg/g untuk mutu karbon aktif teknis berbentuk serbuk. Karbon aktif yang dihasilkan sudah cukup baik, karena efisiensi adsorpsinya yang dapat mencapai 
$50 \%$, artinya karbon aktif yang dihasilkan dapat menjerap biru metilen sebanyak $500 \mathrm{mg} / \mathrm{L}$.

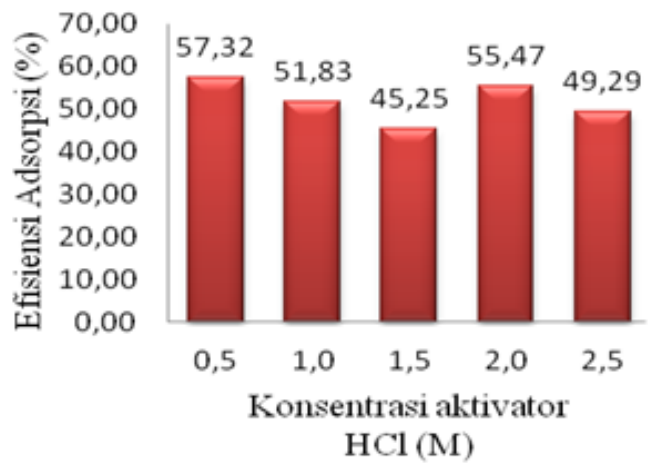

Gambar 4. Efisiensi Adsorpsi Karbon Aktif dengan Aktivator $\mathrm{HCl}$

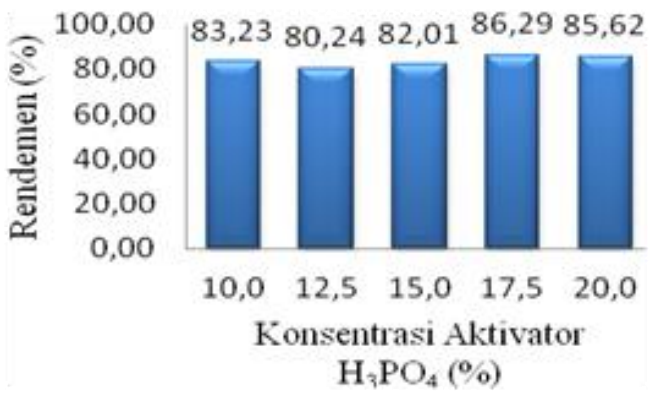

Gambar 5. Efisiensi Adsorpsi Karbon Aktif dengan Aktivator $\mathrm{H}_{3} \mathrm{PO}_{4}$

Zat pewarna metilen biru merupakan pewarna yang umum digunakan di industri tekstil dengan ukuran molekul $19 \mathrm{~nm}$ dan metilen biru memiliki tingkat jerapan yang kuat pada padatan sehingga umum digunakan sebagai model senyawa yang relevan dengan adsorpsi molekul organik dalam bentuk larutan. Adsorpsi metilen biru juga dapat digunakan sebagai parameter penentuan sisi polar dari karbon aktif, makin tinggi nilai adsorpsi maka disinyalir karbon aktif lebih bersifat polar.

Penetapan daya jerap biru metilen dilakukan untuk mengetahui penjerapan larutan berwarna yang memiliki ukuran molekul kurang dari $15 \AA$ atau $1,5 \mathrm{~nm}$. Pengukuran daya jerap karbon aktif terhadap biru metilen menggunakan alat spektrofotometer pada lamda maksimum $664 \mathrm{~nm}$ karena puncak absorbansi maksimum larutan biru terjadi pada lamda tersebut. Kapasitas penjerapan biru metilen merupakan salah satu karakteristik yang harus dimiliki oleh suatu produk karbon aktif. Daya jerap terhadap senyawa ini memiliki kemampuan adsoprsi karbon terhadap senyawasenyawa organik (Sahara et al., 2017).

\section{KESIMPULAN}

Hasil penelitian menunjukan larutan $\mathrm{HCl}$ 0,5000 M merupakan aktivator yang terbaik dalam proses aktivasi karbon TKKS dan memiliki karakteristik yang sesuai syarat SNI No. $06-3730$ - 1995 pada parameter kadar air, kadar abu dan daya jerap terhadap iod.

\section{DAFTAR PUSTAKA}

ASTM International. (2014). ASTM D4607-14, Standard Test Method for Determination of Iodine Number of Activated Carbon. ASTM International. West Conshohocken. PA. www.astm.org.

Badan Standar Nasional. (1995). Arang Teknis. SNI 06-3730-1995. Jakarta.

Efiyanti L., Wati, S.A., \& Maslahat, M. (2020). Pembuatan dan Analisis Karbon Aktif dari Cangkang Buah Karet dengan Proses Kimia dan Fisika. Jurnal Ilmu Kehutanan, 14(1), 94-108.

Faradina, E. \&Setiawati, N. (2010). Regenerasi Minyak Jelantah dengan Proses Bleaching Menggunakan Adsorben Karbon Aktif (Laporan Penelitian). Program Studi Teknik Kimia, Fakultas Teknik, Universitas Lambung Mangkurat, Banjarbaru.

Hardi, A.D., Joni, R., Syukri, \& Aziz, H. (2020). Pembuatan Karbon Aktif dari Tandan Kosong Kelapa Sawit sebagai Elektroda Superkapasitor. Jurnal Fisika Unand, 9(4), 479-486.

Kemenperin. (2017). Ekspor Karbon Aktif. https://kemenperin.go.id/statistik/query_ko moditi.php?

komoditi=activated+carbon\&negara $=\&$ jen is $=$ e $\&$ action $=$ Tampilkan. Diakses September 2019. Kemenperin. 2017. Ekspor karbon aktif https://kemenperin.go.id/statistik/query_ko 
moditi.php?

komoditi=activated+carbon\&negara $=\&$ jen is $=\mathrm{e} \&$ action $=$ Tampilkan. Diakses September 2019

Kurniati, E. 2008. Pemanfaatan Cangkang Kelapa Sawit Sebagai Karbon Aktif. Jurnal Penelitian Ilmu Taknik, 8 (2), 96 - 103.

Laos, L. E. \& Selan, A. (2016). Pemanfaatan Kulit Singkong Sebagai Bahan Baku Karbon Aktif. Jurnal Ilmu Pendidikan Fisika, l(1), $32-36$.

Maslahat, M., Arrisujaya, D., \& Lismayani, S. (2019). Optimasi Suhu Aktivasi Pada Pembuatan Arang Aktif Berbahan Dasar Limbah Tandan Kosong Kelapa Sawit. Prosiding Seminar Lignoselulosa ,46-51.

Meisrilestari, Y., Khomaini,R., \& Wijayanti, H. (2013). Pembuatan Karbon Aktif Dari Cangkang Kelapa Sawit Dengan Aktivasi Secara Fisika, Kimia dan Fisika-Kimia. Jurnal Konversi, 2(1), 46 - 51.

Miranti, S. T. (2012). Pembuatan Karbon Aktif dari Bambu dengan Metode Aktivasi Terkontrol Menggunakan Activating Agent $\mathrm{H}_{3} \mathrm{PO}_{4}$ dan $\mathrm{KOH}$ (Skripsi). Fakultas Teknik, Universitas Indonesia. Depok.

Pakpahan, H., Manurung, G. ME., \& Yulia, A. E. (2013). Aplikasi Kompos Tandan Kosong Kelapa Sawit (Elaeis guineensis Jacq) Terhadap Pertumbuhan Bibit Kelapa Sawit Di Pembibitan Utama. Agro Technology. Fakultas Pertanian. Riau.

Pari, G. (2007). Teknologi Pembuatan dan Uji Mutu Arang, Briket Arang, dan Karbon Aktif. Seminar Tenaga Teknis Penguji HHBK. Pusat Penelitian dan Pengembangan Hasil Hutan. Palembang

Rachmani, F. K. \& Sudibandriyo, M. (2014). Pemanfaatan Tandan Kosong Kelapa Sawit Untuk Produksi Karbon Aktif dengan Aktivasi Kimia. Fakultas Teknik. Universitas Indonesia. Depok.

Rahayu, A. N., \& Adhitiyawarman. (2014). Pemanfaatan Tongkol Jagung Sebagai Adsorben Besi Pada Air Tanah. JKK, 3(3), $7-13$.

Ramdja, A. F., Halim, M., \& Handi, J. (2008). Pembuatan Karbon Aktif dari Pelepah Kelapa (Cocos nucifera). Jurnal Teknik Kimia, 15 (2).

Sahara, E., Dahliani, N. K., \& Manuaba, I. B. P. (2017). Pembuatan dan Karakterisasi Karbon Aktif dari Batang Tanaman Gumitir (Tagetes erecta) yang Diaktivasi dengan Aktivator $\mathrm{NaOH}$. Jurnal Kimia, $11(1), 174-180$.

Sahara, E., Sulihingtyas, W.D. \& Mahardika, I. P. A. D. S. (2017). Pembuatan dan Karakterisasi Karbon Aktif dari Batang Tanaman Gumitir (Tagetes erecta) yang Diaktivasi dengan $\mathrm{H}_{3} \mathrm{PO}_{4}$. Jurnal Kimia, 11(1), $1-9$.

Subadra, I., Setiaji, B., \& Tahir, I. Activated Carbon Production from Coconut Shell With $\left(\mathrm{NH}_{4}\right) \mathrm{HCO}_{3}$ Activator As An Adsorbent in Virgin Coconut Oil Purification. Prosiding Seminar Nasional DIES, 1 - 8. Universitas Gajah Mada.

Tryana, M., \& Sarma, T. (2003). Karbon Aktif (Pengenalan dan Proses Pembuatannya). Jurnal Kimia, 1-9. 